\title{
ROK ŚWIĘTEGO STANISLAWA BISKUPA MĘCZENNIKA W DIECEZJI TARNOWSKIEJ (7 V 1978 - 30 IX 1979)
}

„Rok Stanisławowski” w diecezji tarnowskiej obchodzony pod hasłem Gaude Mater Polonia zrodził się z inspiracji kard. Karola Wojtyły, który podsunął bp. Jerzemu Ablewiczowi pomysł urządzenia tego rodzaju świętowania dziewięćsetnej rocznicy męczeńskiej śmierci św. Stanisława ${ }^{1}$. Z pomysłem zorganizowania w diecezji tarnowskiej „Roku św. Stanisława” bp Jerzy Ablewicz zapoznał dziekanów na spotkaniu z nimi 17 października 1977 roku.

„Pragniemy uczcić św. Stanisława, a zwłaszcza Trójcę Święta, która nam św. Stanisława dała” - powiedział wówczas biskup. „Pragniemy podziękować Bogu za św. Stanisława, któremu tak wiele zawdzięcza nasza diecezja tarnowska... Uroczystość centralna urządzana w Szczepanowie, rozpoczynająca «Rok św. Stanisława» ma więc charakter ogólnodiecezjalnego dziękczynienia. (...)

Naszym korzeniem jest św. Stanisław... Chodzi więc o nasze zapatrzenie się w Niego, zwłaszcza w Jego ofiarę... Stanisław jest wzorem walki o pewne wartości. Umarł za prawdę, za Boże widzenie świata. Na terenie naszej diecezji chodzić będzie przede wszystkim o walkę z pijaństwem.

Zapoznanie z postacią św. Stanisława, zwłaszcza młodzieży, będzie naszym zadaniem pierwszoplanowym.

Chodzi również o to, aby uroczystość szczepanowska jak również «Rok św. Stanisława» stał się ogólnodiecezjalną prośbą, żeby Pan Bóg nad nami się zmiłował. Trudno nam jest przewidzieć, co nas czeka. Tym bardziej, że świat dzisiejszy jest o wiele bliższy sobie, ale wewnątrz jest podzielony i rozdarty"2.

\footnotetext{
'Rok Stanistawowski $w$ diecezji tarnowskiej, „Currenda” 129 (1979), s. 200.

${ }^{2}$ T. S z a r w a r k, Ogólnopolskie uroczystości ku czci św. Stanisława w diecezji tarnowskiej, „Tarnowskie Studia Teologiczne” 7 (1979), s. 328.
} 
Do obchodu „Roku św. Stanisława” bp Ablewicz zaczał przygotowywać wiernych obszernym dwuczęściowym listem pasterskim czytanym w druga i trzecią niedzielę wielkiego postu, 19 i 26 lutego 1978 roku. „W przyszłym roku, 1979, w dniu 11 kwietnia, minie 900 lat od śmierci męczeńskiej św. Stanisława biskupa krakowskiego, jaką poniósł on na Skałce w Krakowie" - pisał biskup w tym liście. „Św. Stanisław urodził się w naszej diecezji we wsi Szczepanów, położonej między Bochnią a Tarnowem. Jest on patronem całej Polski, ale w szczególny sposób św. Stanisław patronuje metropolii krakowskiej i diecezji tarnowskiej. Dlatego uważamy za swój zaszczytny obowiązek uczcić jego męczeństwo uroczystym obchodem na naszej diecezjalnej ziemi"3. Zapowiedział „hołd naszemu świętemu Rodakowi” w Szczepanowie z udziałem Episkopatu Polski, inaugurujący „Rok św. Stanisława” w diecezji tarnowskiej.

Biskup w erudycyjny, a zarazem przystępny sposób przybliżył wiernym postać, męczeństwo, dzieje kultu i znaczenie Świętego narodu i państwa polskiego. Biskup pisał: „Od 900 lat przez śmierć męczeńską św. Stanisława Bóg przemawia do naszych serc i uczy nas umiłowania ponad wszystko Boga i Jego prawa nawet za cenę ofiary z własnego życia. W osobie św. Stanisława Bóg daje nam Znak szlachetnej troski i walki o sprawiedliwość społeczną i prawa człowieka, nawet kosztem największych osobistych wyrzeczeń"4.

„Św. Stanisław żyje w nas. Daje nam bowiem przykład, że w każdej chwili winniśmy myśleć po Bożemu i nie wolno nam kierować się jedynie pojęciami i kategoriami ziemskimi. Św. Stanisław pobudza nas, abyśmy rzeczy, ludzi i wydarzenia i całe życie jednostkowe i społeczne oceniali według Bożej nauki i Bożego prawa, a nie patrzyli na nie nigdy czysto ludzkimi oczami. (...) Stanisław stanął $\mathrm{w}$ obronie podeptanych praw ludzkich i poniósł śmierć za wiarę i sprawiedliwość. (...) Od dziewięciu wieków postać Krakowskiego Biskupa Męczennika stała się dla Polaków symbolem walki o sprawiedliwość społeczną i prawa ludzkie"s. Kult św. Stanisława przez wieki jednoczył Polaków. „Kultura naszej diecezji to kultura przeszłości opromienionej blaskiem św. Stanisława biskupa męczennika, który w dalszym ciagu żyje duchowo w naszej teraźniejszości” - uświadamiał biskup wiernym. „Św. Stanisław jest ciągle wśród nas. Korzenie naszej przeszłości diecezjalnej są korzeniami stanisławowskimi, z których ciagle wyrasta i rozwija się piękna historia wiernego Bogu i Ojczyźnie ludu diecezji tarnowskiej"'.

${ }^{3}$ J. A b l ew i c $\mathrm{z}$, List pasterski zapowiadajacy obchód 900-lecia śmierci męczeńskiej św. Stanistawa ze Szczepanowa, "Currenda” 128 (1978), s. 261.

${ }^{4}$ J. A b l ew i c z, List pasterski zapowiadający obchód 900-lecia śmierci męczeńskiej św. Stanistawa.., s. 264.

${ }^{5}$ Tamże, s. 268.

${ }^{6}$ Tamże, s. 274. 
„Za kilka tygodni, 7 maja, w Szczepanowie rozpoczniemy «Rok św. Stanisława», który zakończymy pielgrzymką do jego grobu w Krakowie w roku przyszłym” - informował biskup. „Pragne gorąco, aby św. Stanisław w ciagu tego roku zjednoczył nas jeszcze ściślej z Bogiem, z Kościołem, z Narodem i między sobą. Pragnę szczególnie, aby w ciagu tego roku św. Stanisław zjednoczył nas wszystkich zwłaszcza w walce o trzeźwość narodu. On jako $Z w y$ cięzca pod mieczem uczy nas, że nie ma prawdziwego zwycięstwa bez ofiary. Tylko przez ofiarę możemy zwyciężyć plage pijaństwa, które niszczy byt biologiczny i duchowy naszego narodu.

$\mathrm{Na}$ ołtarzu jubileuszowym św. Stanisława winniśmy złożyć wotum naszej narodowej trzeźwości. Niechaj tym jubileuszowym wotum będą ożywione i odnowione parafialne księgi trzeźwości. Niechaj w tych księgach znajdą się przede wszystkim imiona i nazwiska naszej młodzieży zdolnej do zwycięstwa nad samym sobą nawet pod mieczem. Oby «Rok św. Stanisława» stał się «Rokiem trzeźwości» na naszej polskiej ziemi, zwłaszcza w tarnowskiej diecezji" ${ }^{\text {"7 }}$.

$\mathrm{Na}$ tydzień przed uroczystością 900-lecia męczeńskiej śmierci św. Stanisława odczytano 30 kwietnia 1978 roku we wszystkich kościołach drugi list bp. Ablewicza, w którym zapraszał na uroczystości stanisławowskie do Szczepanowa pielgrzymów z każdej parafii diecezji tarnowskiej. „Już za tydzień, w najbliższą niedzielę 7 maja zgromadzimy się w Szczepanowie, aby uczcić 900 . rocznicę śmierci męczeńskiej naszego Rodaka, św. Stanisława biskupa krakowskiego" - pisał biskup. „Przybędziemy do Szczepanowa, miejsca urodzenia św. Stanisława, aby uczcić święte korzenie naszego narodu i Kościoła na naszej ziemi. Postać bowiem św. Stanisława, jego życie i śmierć mieszczą się w korzeniach naszego tysiącletniego bytu narodowego i katolickiego. Oto przez 900 lat św. Stanisław swoim przykładem uczy Polaków, że dla zachowania Bożego prawa trzeba być gotowym poświęcić nawet swoje życie. Przez 900 lat św. Stanisław pobudza Polaków do miłowania drugiego człowieka i walki w obronie jego słusznych praw. Przez 900 lat św. Stanisław jednoczy Polaków nieraz tak bardzo poróżnionych i podzielonych. Jednoczy ich najtrwalszymi więzami, które pochodzą od Chrystusa i Kościoła"8.

W niedzielę 7 maja 1978 roku o godzinie 10.30 odbyła się w Szczepanowie zapowiedziana $\mathrm{w}$ listach Biskupa Tarnowskiego uroczystość uprzedzająca o rok 900. rocznicę męczeńskiej śmierci św. Stanisława i rozpoczynająca „Rok św. Stanisława" w diecezji tarnowskiej. Mszę św. pod przewodnictwem kard. Karola Wojtyły koncelebrowali biskupi z diecezji, w której wierni szczególnym

${ }^{7}$ Tamże, s. 271.

${ }^{8}$ J. A b l ew i cz, List Biskupa Tarnowskiego przed uroczystościq 900-lecia śmierci męczeńskiej św. Stanisława Biskupa, „Tarnowskie Studia Teologiczne” 7 (1979), s. 21. 
kultem otaczają św. Stanisława ze Szczepanowa. Na początku Mszy św., po odśpiewaniu przez połączone chóry (700 osób) hymnu Gaude Mater Polonia, przemówił bp Jerzy Ablewicz, który na wstępie odczytał list papieża Pawła VI do Kościoła tarnowskiego na inaugurację „Roku św. Stanisława”. Warto zaznaczyć, że list ten, w którym Ojciec Święty nazwał św. Stanisława niezwyciężonym świadkiem Chrystusa i obrońcą sprawiedliwości, zainspirował bp. Ablewicza do rozwinięcia tych cech Świętego w swoich listach pasterskich i przemówieniach. $Z$ tego względu warto przytoczyć go w całości.

„Do Czcigodnego Brata, Jerzego Ablewicza, biskupa Tarnowskiego w Tarnowie.

Ziemia zostata napetniona męczennikami jakby ziarnem krwi, a z tego ziarna powstat zasiew Kościola. Bardziej świadczyli o Chrystusie zmarli niż żywi. Również dzisiaj o Nim świadczq także dzisiaj Go głoszq: milczy język, wolaja czyny (Św. Augustyn, Mowa 286, 4, 3; Pl 38, 1298). Te słowa, z którymi św. Augustyn zwrócil się do wiernych w rocznicę śmierci męczenników Protazego i Gerwazego, mogą być w pewnym sensie odniesione również do św. Stanisława, biskupa krakowskiego, który w 1079 r. poniósł śmierć jako niezwyciężony świadek religii chrześcijańskiej i obrońca sprawiedliwości.

Jego więc czczą Polacy swymi gorącymi sercami jako niebieskiego Patrona, od niego też w momentach przykrych i trudnych często doznawali opieki.

Kult św. Stanisława powiększał się coraz bardziej w ciągu wieków i niemało przyczynił się do tego, że katolicka Polska wśród tylu doświadczeń dziejowych zachowała swa jedność duchowa (Ef 4,3 ). Wyrazem tej niezwykłej czci są bardzo liczne kościoły poświęcone św. Stanisławowi i to nie tylko w ojczyźnie, ale również poza jej granicami; zwłaszcza zaś w Stanach Zjednoczonych Ameryki Północnej, dokąd wyemigrowali liczni synowie tego narodu. Kościół poświęcony św. Stanisławowi znajduje się również w samym Rzymie.

Uroczystości - które - jak można przewidzieć - będą się odbywać z wielkim zapałem w roku najbliższym, kiedy to będzie obchodzona dziewięćsetna rocznica śmierci tego wielkiego męża, sprawią, iż ten wspaniały pasterz i męczennik zajaśnieje nowym świattem. W diecezji zaś tarnowskiej, która bardzo jest zaszczycona, że na jej terenie, w miejscowości Szczepanów, ten święty się urodził i która zdaje się cieszyć jego specjalną opieką o czym mogą świadczyć rozkwitające tam również obecnie liczne powołania kapłańskie i zakonne, ogłoszony został «Rok Świętego Stanisława», który rozpocznie się 7 maja.

Zamiar ten bardzo pochwalamy i mamy głębokie przeświadczenie, że ten czas wyda obfite owoce duchowe. Niech więc św. Stanisław będzie jakby obecny wśród kapłanów, zgromadzeń zakonnych i wiernych świeckich tej diecezji, by posłużyć się wyżej przytoczonymi słowami św. Augustyna, niech również dzisiaj świadczy o Chrystusie i głosi Chrystusa. On, który był jaśniejącą pochodnią wiary, niech ich umacnia do zachowania wierności Bogu i Kościołowi; on, 
który żyjąc, bronił gorliwie sprawiedliwości, niech ich nakłania do zachowania równości, zwłaszcza w sprawach społecznych, do pielęgnowania wzajemnej przyjaźni, do troski o dobro pokoju.

Takie są życzenia i takie są modlitwy, które płyną z głębi naszego serca. Tobie zaś, Czcigodny Bracie, wszystkim Biskupom polskim, którzy będą uczestniczyć w uroczystościach rozpoczynającego się «Roku Świętego Stanisława», duchowieństwu, zgromadzeniom zakonnym i wszystkim wiernym, którzy są powierzeni Twej opiece pasterskiej, udzielamy apostolskiego błogosławieństwa, które niech będzie zadatkiem niebieskich łask i świadectwem naszej miłosci"?.

Po odczytaniu powyższego listu papieża Pawła VI Biskup Tarnowski przypomniał treści omawiane w swoich listach pasterskich o znaczeniu św. Stanisława dla Kościoła w Polsce ${ }^{10}$. Kazanie wygłosił Prymas Polski kard. Stefan Wyszyński.

„Wielką jest wartość życia, gdy upływa ono w miłości" - mówił Prymas Polski. „A przecież Dawca naszego życia; Ojciec, który jest miłościa, rodzi każdego z nas przez miłość, wszczepia ją w nas i pragnie, abyśmy sami również obfitowali w miłości. Jeżeli życie Stanisława tak obfitowało miłością, że stał się drzewem wrośniętym w polską glebę i w dzieje kultury religijnej Narodu i Kościoła, to najlepszy przykład, jak wielką wartość stanowi miłość. Ona jest największym prawem. Nie ma trwalszego prawa - ani w ustanowieniu Boga, który to prawo wywodzi z siebie, ze swojej miłości, ani też w dziejach ludzi, gdzie pomimo wszystko wyzwala miłość. Nie ma na świecie większych osiągnięć nad to, że ktoś źycie swoje oddaje za braci - jak to uczynił patron tego miejsca, parafii, diecezji, metropolii i całej Polski" "11.

„Wzór Stanisława umierającego na Skałce jest niezwykle trwały" - mówił dalej Prymas Polski. „Umarł za prawdę. Człowiek, który wie, za co umiera, jest mężny. Męstwo chrześcijańskie zawsze łączy się z miłością i prawdą. (...) Jedno życie, a jak rozgałęzione, wydające wspaniałe owoce! Zastanawiamy się, dlaczego pomimo upływu dziewięciu wieków nadal utrzymuje się cześć świętego Stanisława w Polsce i na świecie? Bo Stanisław walczył nie z królem; tylko z jego błędami i grzechami. A my umiemy rozróżniać, o co warto walczyć.

Kościół w obronie Ewangelii i swego posłannictwa musi niekiedy mówić twarde slowa prawdy" - mówił dalej kard. Stefan Wyszyński wyraźnie nawiązując do ówczesnej sytuacji politycznej kraju. „Nie walczy jednak z ludźmi,

\footnotetext{
${ }^{9}$ Watykan, 11 IV 1978.

${ }^{10}$ Przemówienie biskupa Jerzego Ablewicza w Szczepanowie - 7 V 1978 r., „Currenda” 128 (1978), s. 280-282

${ }^{11}$ Kazanie kardynała Stefana Wyszyńskiego w Szczepanowie - 7.V.1978, „Currenda” 128
} (1978), s. 285. 
tylko $\mathrm{z}$ ich błędami i grzechami, z niesprawiedliwością i krzywdą której się dopuszczają. Jak Stanisław walczył z błędami i grzechami i przez to stał się sztandarem ładu społecznego, tak i Kościół nie walczy z ludźmi, lecz z grzechami, błędami, nadużyciami i niesprawiedliwościa, ukazuje problemy, które należy rozwiazać, aby uniknąć gorszych jeszcze nieszczęść" ${ }^{12}$.

Pod koniec Mszy św. przemawiali metropolita krakowski kard. Karol Wojtyła i Georges Singha biskup Ovando w Kongo Brazzaville, gdzie wówczas pracowało siedmiu polskich misjonarzy i cztery siostry zakonne pochodzący $\mathrm{z}$ diecezji tarnowskiej.

Biskup tarnowski odmówił ułożoną przez siebie Modlitwe ludu Bożego diecezji tarnowskiej do św. Stanistawa swego patrona. W modlitwie tej biskup zawierzył św. Stanisławowi wszystkich diecezjan. Tę dwuczęściową modlitwę - świadectwo duszpasterskiego zatroskania gorliwego pasterza o życie religijno-moralne wspólnot parafialnych i pojedynczych wiernych warto przytoczyć w całości.

\section{I}

Oto ten przeznaczony jest na powstanie wielu i na Znak... (Lk 2, 34).

Święty Stanisławie, Biskupie Męczenniku, nasz Rodaku i Patronie, dziękujemy Bogu w Trójcy Świętej Jedynemu za to, że dał nam Ciebie, a zwłaszcza Twoją śmierć męczeńską jako niezawodny Znak miłości Boga i ludzi.

$Z$ łaskawej woli Boga przez dziewięć stuleci uczysz nas Swoim przykładem, że dla zachowania Bożego prawa winniśmy poświęcić wszystko, nawet nasze życie.

Przez dziewięć stuleci pobudzasz nas, św. Stanisławie, abyśmy za Twoim wzorem pomagali drugiemu człowiekowi i bronili jego słusznych praw nawet za cenę największej ofiary.

Przez dziewięć stuleci w przedziwny sposób jednoczysz Polaków z Bogiem i między sobą.

Twoje męczeńskie ciało nie zostało porąbane i podzielone na darmo. Zasługi bowiem i przykład Twojego męczeństwa sprawiały, że męczeńskie ciało naszego narodu tylekroć w ciagu wieków podzielone przez waśnie, nienawiść i walkę zrastało się z powrotem do życia zgodnego w bratniej miłości. Twoje zasługi i przykład przyczyniły się, że męczeńskie ciało naszego narodu porąbane rękami zaborców powstało zjednoczone do niepodległego bytu państwowego po 150 latach niewoli.

${ }^{12}$ Tamże, s. 287-288. 
Drogi nasz Patronie, przez dziewięć stuleci swoim wstawiennictwem u Boga oświecasz watpiących i niewierzących, dźwigasz z błota występków grzesznych, wzmacniasz na drodze cnoty sprawiedliwych, pocieszasz smutnych, chorych i cierpiących.

Św. Stanisławie, diecezja nasza czci jako swoich głównych patronów Najświętszą Maryję Pannę, którą tak bardzo miłowałeś, a wraz z Nią Ciebie, Chwalebny Biskupie Męczenniku. Jesteśmy przekonani i wdzięczni Bogu, że przez 900 lat Ty, Święty nasz Rodaku, prowadzisz synów i córki diecezji tarnowskiej pod opiekuńczy płaszcz Matki Boga i ludzi.

Prowadzisz nas, a zwłaszcza nasze rodziny przez Maryję do Jezusa i przez to stałeś się Ojcem wiary i pobożności ludu tarnowskiej diecezji, a zwłaszcza Ojcem licznych powołan kapłańskich i zakonnych na naszej diecezjalnej ziemi.

Ciesz się, Matko Polsko. Cała Polska raduje się w Tobie, Św. Stanisławie, jako w swoim szlachetnym Synu i czułym Patronie. W szczególny sposób raduje się w Tobie, jako w swoim Synu i Patronie, nasza Diecezja i tę swoją radość wyraża w płynącym z głębi serc hymnie Ciebie Boga wychwalamy.

\section{II}

Matka (Polska) placzqc raduje się w Swoim Synu, ponieważ On żyje jako Zwycięzca pod mieczem. Alleluja.

Święty nasz Patronie Stanisławie, Zwycięzco pod mieczem. Chociaż Twoja głowa padła pod mieczem prześladowcy, stałeś się Zwycięzcą. W ten sposób uczysz nas nieustannie, że tylko przez ofiarę możemy zwyciężyć wszelkie zło w sobie i w drugich. Dlatego błagamy Cię dzisiaj nade wszystko o ducha ofiary, bez której nie ma prawdziwej miłości Boga i Ojczyzny, sprawiedliwości społecznej i czystości obyczajów.

Za nasze dzieci, aby od najmłodszych lat uczyły się przez ofiarę zwyciężać w sobie złe skłonności, prosimy Cię, Święty Stanisławie (powtarzają wszyscy obecni).

Za naszą młodzież, aby przez ofiarę zwyciężała obojętność we wierze, rozwiązłość, nietrzeźwość, wygodnictwo, gwałt i przemoc dzisiejszego świata, prosimy Cię, Święty Stanisławie.

Za naszych małżonków, aby przez ofiare zwyciężali to wszystko, co godzi w ich miłość, wierność i uczciwość małżeńską oraz ochotnie podejmowali trud zrodzenia i wychowania potomstwa i nigdy nie plamili się grzechem dzieciobójstwa, prosimy Cię, Święty Stanisławie.

Za nasze rodziny, aby przez ofiarę codziennej wspólnej modlitwy, zwłaszcza różańcowej, niedzielnej Mszy św. i szczerej pokuty zwyciężali świeckie 
i bezbożne obyczaje, które chcą wtargnąć poza progi ich domów, prosimy Cię, Święty Stanisławie.

Za nasze społeczeństwo, aby przez ofiarę zwyciężyło straszliwy nałóg pijaństwa, który prowadzi je do ruiny duchowej i materialnej, prosimy Cię, Święty Stanisławie.

Za naszych biskupów, kapłanów, kleryków, zwłaszcza tarnowskiego Seminarium Duchownego i siostry zakonne, aby przez ofiarę zwyciężali ducha świata, który nie da się pogodzić ze świętością kapłańską i zakonnymi ślubami, prosimy Cię, Święty Stanisławie.

Za naszych młodzieńców i panny, których Bóg powołuje na swoją wyłączną służbę, aby przez ofiarę zwyciężali to wszystko, co ich chce odwieść od całkowitego poświęcenia się Bogu w kapłaństwie i życiu zakonnym, prosimy Cię, Święty Stanisławie.

Za naszych chorych, cierpiących, smutnych i płaczących, aby przez ofiarę cierpliwości podejmowaną za Twoim przykładem na każdy dzień byli zwycięzcami pod mieczem, prosimy Cię Święty Stanisławie.

Za nasz naród, aby przez ofiarę tych, którzy nim rządzą i przez ofiarę swoich obywateli zwyciężał wszystko, co zagraża jego szlachetności duchowej, tradycjom, pomyślności materialnej i pokojowi, prosimy Cię, Święty Stanisławie.

Święty Stanisławie, Biskupie Męczenniku, weź w szczególną opiekę lud diecezji tarnowskiej, który szczyci się, że Bóg dał mu Ciebie za swego Rodaka. Jesteśmy dumni, że korzeniem duchowym naszego diecezjalnego drzewa stał się Chrystus właśnie przez Ciebie i Twoją śmierć męczeńską. Nie dopuść, aby ktokolwiek z nas miał odpaść od tego świętego Chrystusowego korzenia. Niechaj z tego świętego korzenia poprzez dalsze stulecia wyrastają gałęzie uczciwości, szlachetności i świętości życia naszych dzieci, młodzieńców, panien, ojców, matek, kapłanów, sióstr zakonnych i zawsze licznych kandydatów do kapłaństwa na tarnowskiej ziemi.

Drogi nasz Rodaku, Patronie. Prowadź zawsze, także w drugim Tysiącleciu, swoich braci i siostry tarnowskiej diecezji do Maryi a przez Nią do Jezusa. Amen"13.

Na zakończenie Mszy św, kard. Karol Wojtyła udzielił pielgrzymom zebranym wokół ołtarza polowego uroczystego błogosławieństwa relikwiarzem z czaszką Świętego, którą przywiózł z katedry wawelskiej. Ogółem w tym uroczystym nabożeństwie wzięło udział 44 biskupów z Polski i z zagranicy.

${ }^{13}$ J. A b l e w i c z, Modlitwa ludu Bożego diecezji tarnowskiej do św. Stanistawa swego patrona w 900-tnq rocznice jego męczeńskiej śmierci, „Currenda” 128 (1978), s. 291-293. 
Warto dodać, że w ową niedzielę (7 maja 1978) przytoczoną wyżej modlitwę odmówiono także we wszystkich kościołach diecezji, na wszystkich nabożeństwach, zaś po głównej Mszy św. przed wystawionym Najświętszym Sakramentem. Biskup zalecał, aby po pierwszej jej części odśpiewać hymn Ciebie Boga wychwalamy, a na zakończenie pieśn do św. Stanisława ${ }^{14}$. W całej diecezji w owym dniu głoszono kazania o św. Stanisławie, których temat brzmiał Gaude Mater Polonia.

Na tę uroczystość parafia szczepanowska przygotowała się przez trzydniowe rekolekcje. Sam zaś dzień głównych uroczystości został poprzedzony całonocnym czuwaniem, na które złożyły się uroczyste nieszpory, godzina biblijna i Droga krzyżowa. O północy biskup pomocniczy Piotr Bednarczyk odprawił uroczystą Mszę św. połączoną z procesją teoforyczna. Nad ranem wierni odmawiali różaniec. Sam zaś uroczysty dzień rozpoczęli Godzinkami o Niepokalanym Poczęciu Najświętszej Maryi Panny.

Po głównej uroczystości niedzielnej przez tydzień (8-14 maja) trwała jej oktawa. Każdy jej dzień miał swoje hasło określające charakter przybywających grup pielgrzymów. W poniedziałek pod hasłem Sw. Stanisław wychowawcq rodzin kapłańskich zgromadzili się rodzice kapłanów i sióstr zakonnych. Wtorkowe zawołanie $S$ w. Stanisław patron ojczyzny ściagnęło do Szczepanowa weteranów walk o wolną Polskę i byłych więźniów obozowych. Środa $\mathrm{z}$ hasłem $\mathrm{Ma}$ ryja matka swiętych na polskiej ziemi była dniem sanktuariów w diecezji tarnowskiej. Św. Stanisław patron powołan zgromadził we czwartek kleryków diecezjalnych i zakonnych z Krakowa, Częstochowy, Tarnowa, Sędziszowa i Tuchowa. Piątek był dniem chorych i cierpiących oraz sióstr miłosierdzia. Pod hasłem $S^{\prime} w$. Stanistow patron cierpiacych zgromadzili się chorzy wraz ze służbą zdrowia. W sobote z zawołaniem Sw. Stanistaw wzorem oddania się Bogu wspólnotę modlitewną tworzyło 500 sióstr zakonnych i około 3000 młodzieży ze służby liturgicznej. Niedzielę, zakończenie oktawy, świętowano pod hasłem Gaude Mater Polonia. Sumę odprawił bp Piotr Bednarczyk ${ }^{15}$.

Cały wysiłek duszpasterski w „Roku św. Stanisława” nie ograniczał się do przypominania wiernym samych wydarzeń z życia Świętego, ale przede wszystkim skupiał sie na umacnianiu ich przekonań religijnych i formowaniu postaw moralnych. Szczególny nacisk położono na walkę o trzeźwość diecezjan. W celu osiagnięcia tych celów pracę formacyjną ustawiono na trzech poziomach: parafialnym, dekanalnym i diecezjalnym.

We wszystkich parafiach, w każdej klasie szkoły podstawowej i średniej przeprowadzono specjalne katechezy, w których starano się przekazać dzieciom

\footnotetext{
${ }^{14}$ Tamże, s. 293.

${ }^{15}$ T. S z a r w a rk, Ogólnopolskie uroczystości..., dz. cyt., s. 330-334.
} 
i młodzieży najważniejsze wiadomości o życiu św. Stanisława i jego znaczeniu dla polskiej kultury religijnej. Przede wszystkim zwracano uwage na postawę moralną św. Stanisława i jego troskę o te wartości, na których Polacy budowali swój byt narodowy.

W „Roku Stanisławowskim” organizowano w diecezji różnego rodzaju nabożeństwa bądź to $\mathrm{w}$ ramach parafii, bądź dekanatu. Do nabożeństw parafialnych należały tridua stanowe, osobne dla ojców, matek i młodzieży. Uczestnicy ich mogli przemyśleć swoje aktualne sprawy życiowe w blasku postaci św. Stanisława. Diecezjanie tarnowscy pielgrzymowali w ramach poszczególnych dekanatów do wyznaczonych kościołów $w_{4}$ aby tam lepiej zapoznać się z życiem i dziełem św. Stanisława. Bp Jerzy Ablewicz przywiązywał wielką wagę do tych nabożeństw. Przyjeżdżał wtedy do dekanatu, celebrował Mszę św. i głosił homilię. Niejednokrotnie nabożeństwo poprzedzała akademia poświęcona św. Stanisławowi. Przez te pielgrzymki przewinęły się setki tysięcy wiernych.

Do Szczepanowa przez cały rok przyjeżdżali pielgrzymi nie tylko $z$ diecezji tarnowskiej, lecz również z innych stron Polski, a także z zagranicy. Pielgrzymi przybywający pojedynczo lub grupowo uczestniczyli we Mszy św. i przyjmowali Komunię św. Najczęściej przybywały grupy zorganizowane, zwykle z kapłanem. Najczęściej były to pielgrzymki służby liturgicznej (ministrantów i lektorów), dzieci po I Komunii św. i młodzieży po bierzmowaniu.

Zgodnie z życzeniem Pasterza diecezji niemal wszyscy księża odprawili kapłańskie rekolekcje „Stanisławowskie" osnute wokół postaci Świętego Biskupa Męczennika. Te ćwiczenia duchowne odbyli bądź to przez trzy dni w Seminarium Duchownym lub Domu Rekolekcyjnym w Ciężkowicach, bądź to przez pięć dni w willi „pod Krzyżem” w Kościelisku koło Zakopanego. Dwie serie głosił sam bp Ablewicz. Pozostałe zaś o. Jan Wojnowski redemptorysta.

W ciagu owego roku wygłoszono $\mathrm{w}$ diecezji wiele prelekcji naukowych ukazujących prawdę historyczną o św. Stanisławie. Wydano tom „Tarnowskich Studiów Teologicznych" poświęcony temu Świętemu. Klerycy tarnowskiego Seminarium Duchownego rok akademicki $1977 / 78$ przeżywali pod hasłem starodawnego hymnu ku czci św. Stanisława Gaude Mater Polonia.

Zespół księży diecezjalnych opracował trzy zestawy czytanek o św. Stanisławie, po dziesięć każdy na nabożeństwa majowe i październikowe. Ponadto w różnych parafiach wyświetlono film $\mathrm{z}$ uroczystości stanisławowskich w Szczepanowie ${ }^{16}$.

${ }^{16} \mathrm{~J}$. A ble w i c z, List Biskupa Tarnowskiego zapowiadajacy diecezjalnq pielgrzymke na Wawel i Skatke w Krakowie na zakończenie roku św. Stanistowa, „Tarnowskie Studia Teologiczne" 7 (1979), s. 35-36; Rok Stanistawowski..., s. 200-201; T. S z a rwark, Sprawozdanie $z$ obchodu Roku Stanisławowskiego i jego zakończenie na Wawelu i Skałce w Krakowie, „Currenda" 130 (1980), s. 202-203. 
Dwie wystawy urządzone w Szczepanowie miały na celu przybliżenie pielgrzymom, zwłaszcza młodzieży, postaci św. Stanisława i ukazanie wielkiego wpływu, jaki w ciagu wieków wywierał na dzieje i kulturę Polaków. W kościele pod wezwaniem św. Stanisława (na cmentarzu) znajdowała się wystawa Święty Stanisław Szczepanowski - żcie, męczeństwo, chwala. Scenariusz tej wystawy opracował ks. Władysław Szczebak, zaś oprawę plastyczną wykonał artysta malarz J. Szuszkiewicz ${ }^{17}$. W zabytkowym spichlerzu stojącym tuż obok plebanii mieściła się wystawa sztuki ludowej z motywami Stanisławowskimi, zorganizowana $z$ inicjatywy i przy osobistym staraniu bp. Piotra Bednarczyka ${ }^{18}$.

„Rok Stanisławowski" w diecezji tarnowskiej został zamknięty 30 września 1979 roku ogólnodiecezjalną pielgrzymką na Wawel i Skałkę w Krakowie. Od wczesnych godzin rannych zaczęły owego dnia gromadzić się grupy pielgrzymów z różnych regionów diecezji. Przychodzili w grupach, najczęściej z księdzem na czele. W większości byli to ludzie młodzi. Niektóre grupy były ubrane w regionalne stroje ludowe. Uroczystej Mszy św. koncelebrowanej na ołtarzu polowym na placu przed katedrą przewodniczył Biskup Tarnowski, który także wygłosił kazanie. „Fundamentem religii, sprawiedliwości i chwały polskiego narodu (...) na przestrzeni 900 lat były kości męczeńskie św. Stanisława" - mówił biskup. „Stanisław stanął w obronie więzów duszy polskiej z Bogiem. (..) Przez setki lat św. Stanisław był symbolem walki przede wszystkim o prawa Boga" i prawa człowieka. Życie pobożne, uczciwe i trzeźwe wymaga poświęcenia $\mathrm{i}$ ofiary. „Myśmy $\mathrm{w}$ tym roku położyli szczególny nacisk na walkę o trzeźwość, na walkę z pijaństwem. Nie chcemy jej zakończyć. Pragniemy tym rokiem św. Stanisława zacząć nasze dalsze, jeszcze mocniejsze wysiłki, aby znikła z oblicza narodu polskiego ohydna plama pijaństwa. (...) Pragniemy, aby w każdej parafii naszej diecezji powstały Koła św. Stanisława do walki z tym strasznym nałogiem pijaństwa, które nas odziera z narodowej chwały"19.

Po kazaniu biskup odmówił, przytoczoną już, Modlitwę ludu Bożego diecezji tarnowskiej, kfórą modlił się przed przeszło rokiem w Szczepanowie. Po południu o godzinie 14.00 pielgrzymi zgromadzili się na Skałce, miejscu męczeńskiej śmierci św. Stanisława, gdzie uczestniczyli w nieszporach, którym przewodniczył biskup pomocniczy Piotr Bednarczyk. Kazanie do wiernych zebranych przed kościołem św. Michała Archanioła wygłosił bp Jerzy Ablewicz, który powiedział: „Nasza nadzieja chrześcijańska winna mieć koloryt stanisła-

${ }^{17}$ W. S z c z e bak, Wystawa poświęcona postaci św. Stanisława B.M. w Szczepanowie, „Currenda" 128 (1978), s. 306-309.

${ }^{18}$ N. L i p p ó c z y, Wystawa sztuki ludowej w Szczepanowie, tamże, s. 309-315.

${ }_{19} \mathrm{~J}$. A b lew i cz, Przemówienie wygłoszone na Wawelu $w$ Krakowie $w$ czasie ogólnodiecezjalnej pielgrzymki na zakończenie „Roku sw. Stanisława” w diecezji tarnowskiej. 30 IX 1979 r., "Currenda" 130 (1980), s. 188-190, 192. 
wowski. Możemy bowiem powoływać się na św. Stanisława jako na Arcykapłana, który $\mathrm{z}$ nas wzięty, dla ludzi żył i za ludzi umarł i w niebie dzisiaj na podobieństwo Chrystusa żyje, aby się ciagle wstawiać za nami, a zwłaszcza za swoją rodzinną diecezją. Chodzi tylko o to, abyśmy się do niego modlili. (...) Postanówmy w każdą niedzielę i święto śpiewać w naszych kościołach nieszpory. (...) Niech temu śpiewowi towarzyszy zawsze to zapatrzenie się w św. Stanisława, który jest fundamentem naszej religii, sprawiedliwości i fundamentem naszej chwaty"20.

Jakie były owoce „Roku św. Stanisława” w diecezji tarnowskiej? W owym jubileuszowym roku św. Stanisław był jakby szczególnie obecny w Kościele tarnowskim. Diecezja „Rok św. Stanisława” przeżyła w duchu wiary, pogłębienia świadomości religijnej i odnowy moralnej. Był to czas dziękczynienia całej wspólnoty diecezjalnej za wszystkie łaski, jakie otrzymała od Boga przez wstawiennictwo swego Patrona. Główną akcją duszpasterską „Roku św. Stanisława” była walka z pijaństwem, zainicjowana przez bp. J. Ablewicza w jego liście pasterskim zapowiadającym obchód 900-lecia śmierci męczeńskiej św. Stanisława. Dlatego był to czas ogólnodiecezjalnej usilnej prośby o trzeźwość i podjęcia walki z pijaństwem. W ramach Parafialnego Apostolatu Trzeźwości powstały tzw. Koła św. Stanisława, których zadaniem było propagowanie wstrzemięźliwości od napojów alkoholowych w różnych środowiskach pracy i wypoczynku.

W diecezji tarnowskiej nastapiło wyraźne ożywienie kultu św. Stanisława. Wzrosło zainteresowanie postacią Świętego Biskupa Męczennika. Przede wszystkim przyczyniły się do tego listy pasterskie i przemówienia bp. Jerzego Ablewicza, który żywił osobiste nabożeństwo do tego Świętego. Ukazanie św. Stanisława jako „Patrona Polaków” pozwoliło wiernym całej diecezji spojrzeć na niego nie tylko w czerwieni jego męczeńskiej krwi, ale i w barwach białoczerwonych, jako na tego, który ,jest krew z krwi i kość z kości” Polakiem i wstawia się u Boga za swoim narodem. Zapewne takie ukazanie postaci Stanisława ożywiało uczucia religijne i patriotyczne. Wyrazem tego wzmożonego zainteresowania było częstsze nadawanie dzieciom imienia Stanisław przy chrzcie. Znaczna liczba kandydatów do sakramentu bierzmowania wybierała sobie to imię. Liczne zaś pielgrzymki przyczyniły się do pogłębienia więzi diecezjalnej $^{21}$. Obchód „Roku św. Stanisława” w diecezji tarnowskiej walnie przyczynił się do podniesienia świadomości religijno-moralnej wiernych.

${ }^{20} \mathrm{~J}$. A b l e w i c z, Przemówienie wygłoszone w czasie nieszporów na Skatce z racji zakończenia obchodu 900-lecia śmierci św. Stanisława 30 LX 1979, „Currenda” 130 (1980), s. 194-195.

${ }^{21}$ P. B[ednarczyk?], Rok św. Stanislawa BM w diecezji tarnowskiej (7 V 1978-30 LX 1979), „Currenda" 130 (1980), s. 196-197. 


\section{Year of St. Stanislaus, Bishop and Martyr In Tarnów's Diocese \\ (May 7, 1978 - September 30, 1979) \\ Summary}

The idea of "St. Stanislaus'Year" in Tarnów's diocese was inspired by cardinal Karol Wojtyła, who prompted it to bishop Jerzy Ablewicz to commemorate the ninehundredth anniversary of a martyr's death of St. Stanislaus.

On Sunday, May 7, 1978 a celebration took place in Szczepanów, as announced in the letters of the Bishop of Tarnow the year before the nine-hundredth anniversary of a martyr's death of St. Stanislaus, thus marking the beginning of the 'Year of St. Stanislaus' in Tarnów's diocese. Cardinal Karol Wojtyła presided over a Holy Mass, which was concelebrated by the bishops of the dioceses in which St. Stanislaus of Szczepanow is especially venerated. The homily was preached by the Primate of Poland, cardinal Stefan Wyszyński. The Bishop of Tarnów said a prayer which he had written for the occasion: A prayer of the congregation of the diocese of Tarnow to St. Stanislaus, its patron saint. The Mass ended with cardinal Karol Wojtyła's solemn blessing extended to the pilgrims gathered at the field-altar with the reliquary with the Saint's skull, which had been brought from the Wawel Cathedral. In this solemn service participated 44 bishops from Poland and from abroad. The main Sunday ceremony was followed by its octave (from May 8 to 14). Pilgrims from Tarnów's diocese and from other parts of Poland and from abroad were coming to Szczepanów throughout the year. 'St. Stanislaus' Year' in the diocese of Tarnów finished on September 30, 1979 with an all-diocesan pilgrimage to Wawel and Skałka in Cracow.

The "Year of St. Stanislaus' was the time of deepening religious awareness as well as moral and spiritual revitalisation of the diocese. Pastoral activity was focused primarily on the strengthening of religious beliefs and forming moral attitudes of the faithful. A special emphasis was laid on the sobriety of the diocesans. Within the Parish Apostolate of Sobriety, the so called Circles of St. Stanislaus were created with an aim to propagate abstemiousness from alcoholic beverages. A visible enlivening of the worship of St. Stanislaus in the diocese was observed. 